\title{
Utility of Dried Distillers Grain as a Fertilizer Source for Corn
}

\author{
Kelly A. Nelson (Corresponding author) \\ Division of Plant Sciences, University of Missouri \\ PO Box 126, Novelty, MO 63460 \\ Tel: 1-660-739-4410Ｅ-mail: nelsonke@missouri.edu
}

Peter P. Motavalli

Department of Soil, Environmental and Atmospheric Sciences, University of Missouri

333 AB Natural Resources Building, Columbia, MO 65211

Tel: 1-573-884-3212 E-mail: motavallip@missouri.edu

Randall L. Smoot

Greenley Research Center, University of Missouri

PO Box 126, Novelty, MO 63460

Tel: 1-660-739-4410Ｅ-mail: smootr@missouri.edu

\begin{abstract}
Increased ethanol production may result in excessive dried distillers grains (DDGs) that could be utilized as a fertilizer source for corn (Zea mays L.). Research was conducted to evaluate the effects of 1) DDG rates on weed suppression, changes in soil properties, and differences in grain yield and quality and 2) DDGs, polymer-coated urea (PCU), and anhydrous ammonia (AA) fertilizer sources on grain yield and quality. DDGs had a total N-P-K composition of 38.2-6.9-11.5 g kg${ }^{-1}$, respectively. There was no corn injury, common cocklebur or jimsonweed control with DDG rates up to $3600 \mathrm{~kg} \mathrm{ha}^{-1}$. Corn grain yield increased 1.41 and $1.56 \mathrm{~kg} \mathrm{ha}^{-1}$ for every kg ha ${ }^{-1}$ of DDGs applied in medium and high yield environments, respectively. Grain yield was ranked non-treated control $<$ DDGs $\leq$ AA $=$ PCU when fertilizers were applied at $\mathrm{N}$ equivalent rate of $140 \mathrm{~kg} \mathrm{ha}^{-1}$ in medium and high yield environments.
\end{abstract}

Keywords: Soil amendment, Nitrogen, Organic, Weed control, Anhydrous ammonia, Polymer-coated urea

\section{Introduction}

Ethanol production in the U.S. has created new jobs in rural communities, increased the amount of land area cropped to corn (Zea mays L.), stimulated higher local grain prices, and raised the amount of corn used by the dry-milling industry in the Midwest (Parcell \& Westhoff, 2006). Dried distillers grains (DDGs) are a co-product of converting corn into ethanol. Continued growth in ethanol production may create a surplus of DDGs (Erickson, Klopfenstein, Adams, \& Rasby, 2005; Rausch \& Belyea, 2006) and alternative uses for this material may be needed. DDGs are commonly fed to livestock as a protein source in the wet or dry form as a yellow meal (Erickson et al., 2005; Harris, Cupp, Roberts, \& Funston, 2008; Martin, Cupp, Rasby, Hall, \& Funston, 2007; Martinez Amezcula, Parsons, \& Noll, 2004). DDGs are an excellent source of phosphorus and other nutrients in the diets of livestock (Belyea, Rausch, \& Tumbleson, 2004; Erickson et al., 2005; Harris et al., 2008; Martinez Amezcula et al., 2004; Rausch \& Belyea, 2006).

A portion of plant nutrient elements contained in land-applied DDGs should become available to the plant over the growing season through the decomposition process similar to manure and other compost materials (Gale et al., 2006). Several studies have evaluated the effect of compost, livestock manure (Eghball, 2002; Gale et al., 2006; Lithourgidis, Matsi, Barbayiannis, \& Dordas, 2007; Singer et al., 2004), oily feed wastes (Rashid \& Voroney, 2004), paper mill solids (Aitken, Evans, \& Lewis, 1998; Curnoe, Irving, Dow, Velema, \& Unc, 2006; N'Dayegamiye 2006), organic fertilizers, and biofertilizers (Jilani et al., 2007) on crop production. Manure, compost, and organic fertilizer research has reported corn grain yields similar (Lithourgidis et al., 2007) or lower (Jilani, et al., 2007) than comparable 
applications of synthetic N-P-K fertilizers. Among the additional benefits of using organic soil amendments, such as manure, are improvements in soil physical biological and chemical properties, including increased soil water-holding capacity, aggregation, cation exchange capacity, decreased soil erosion, and addition of micronutrients which may be deficient when only synthetic N-P-K fertilizers are applied (Edwards, Burt, Raper, \& Walker, 1995). Potential problems with land application of organic soil amendments include the possible presence of toxic substances (e.g., excessive micronutrients or other trace elements, industrial byproducts, and agrochemicals) and biological pathogens, odor, and salinity (Stevenson, 1985).

Increased use of corn for ethanol production may also lead to use of corn contaminated with aflatoxin (Aspergillus flavus). Aflatoxins are not affected by fermentation, but are concentrated in the DDGs. This may be particularly important to ethanol plants located near drought-prone, claypan soils (Blanco-Canqui, Gantzer, Anderson, Alberts, \& Ghidey, 2002). Disposal of aflatoxin-contaminated DDGs as fertilizer grade material may provide ethanol facilities with an alternative use for a product with no animal feed value. No research has evaluated the impact of DDGs on crop and weed response as a fertilizer source or a possible preemergence herbicide in crop production systems. Therefore, the objectives of this research were to: 1) evaluate the effect of DDG rates on weed suppression, changes in soil properties, and relative grain yield and quality; and 2) evaluate grain yield and quality response to DDGs with slow release urea and anhydrous ammonia fertilizer sources at an equivalent $\mathrm{N}$ source application rate.

\section{Materials and methods}

\subsection{General methods}

Field research was conducted at the University of Missouri Greenley Research Center near Novelty $\left(40^{\circ} 01^{\prime} \mathrm{N}, 9^{\circ} 11^{\prime}\right.$ W) on a Putnam silt loam (fine, smectitic, mesic Vertic Albaqualfs) from 2003 to 2007 in the DDG rate experiment and from 2004 to 2007 in the $\mathrm{N}$ fertilizer source experiment. The experiments were arranged in randomized complete block designs with four replications. Locally produced DDGs (POET Biorefining, Macon, MO) were collected from three of the four replications each year prior to application and analyzed for chemical and mineral properties using recommended manure analysis methods for total $\mathrm{N}$, ammonium- $\mathrm{N}, \mathrm{P}, \mathrm{K}, \mathrm{Ca}, \mathrm{Zn}, \mathrm{Fe}, \mathrm{Mn}, \mathrm{Cu}, \mathrm{pH}$, and electrical conductivity (Peters et al., 2003). A 1:2 solid:water solution was used for determining pH, electrical conductivity, and ammonium-N. The average analyses of DDGs are presented in Table 1. DDGs were broadcast-applied using a hand spreader following planting. The experiments were conducted on previously untreated areas of the same field following soybean [Glycine max (L.) Merr.] each year. Grain yield was determined using a Massey Ferguson 10 small plot combine (Kincaid Equipment Manufacturing, Haven, KS) to harvest the center two rows. Grain moisture was adjusted to $150 \mathrm{~g} \mathrm{~kg}^{-1}$ prior to analysis. Grain samples were collected and ten subsamples analyzed for oil, protein, starch, and extractable starch with a Foss 1241 (Eden Prairie, MN) near infrared spectrometer using previously established calibrations (Paulsen, Pordesimo, Singh, Mbuvi, \& Ye, 2003; Paulsen \& Singh, 2004; Singh, Paulsen, Tian, \& Yao, 2005).

\subsection{DDG rates}

This site had been in an organic corn-soybean production system for six years prior to the initiation of this research. Initial soil test characteristics are presented in Table 2. Plots were 3 by $15.2 \mathrm{~m}$. The soil was fall or spring moldboard plowed, spring field cultivated, and cultipacked smooth prior to planting. An 'NC+112E1' organic corn hybrid was planted at 59280 to 64220 seeds ha $^{-1}$ on 27 May 2003, 6 May 2004, 10 May 2005, 24 April 2006, and 22 May 2007. DDGs were broadcast-applied prior to crop and weed emergence at $0,1200,2400$, and $3600 \mathrm{~kg} \mathrm{ha}^{-1}$ with an average of $102.0 \pm 1.39 \mathrm{~g} \mathrm{~kg}^{-1}$ moisture. The $1200 \mathrm{~kg} \mathrm{ha}^{-1}$ rate was equivalent to an N-P-K application rate of $46-8-14 \mathrm{~kg} \mathrm{ha}^{-1}$ based on total nutrient content (Table 1).

All plots were rotary hoed twice and cultivated up to three times following planting for weed control. In-row weed control with DDGs was evaluated approximately 8 weeks after planting. Weed control was based on the effects of DDGs on a combined visual score $(0=$ no visual injury to $100=$ complete plant death $)$ of weed stunting and reduction in population density. The primary weed species present were common cocklebur (Xanthium strumarium L.) and jimsonweed (Datura stramonium L.). Soil was sampled using a composite of 20 soil cores in the fall or early the following spring using a stainless steel push probe to a depth of $15 \mathrm{~cm}$ to evaluate the effects of DDGs on selected soil properties.

\subsection{DDGs and conventional N sources}

Polymer-coated urea (ESN, Agrium, Calgary, AB) and DDGs were broadcast-applied while anhydrous ammonia was knife-injected below the soil surface prior to planting at an equivalent of $140 \mathrm{~kg} \mathrm{~N}^{-1}$ in plots 3 by $12.2 \mathrm{~m}$. The DDG rate calculation was based on total $\mathrm{N}$ (Table 1). Treatments were applied to non-treated portions of the field following soybean each year. 'RX 752RR/Bt' was no-till planted at 74100 seeds ha ${ }^{-1}$ on 9 April 2004, 3 May 2005, 28 April 2006, and 23 April 2007. Crop injury due to the DDG treatment was evaluated 7, 14, and $21 \mathrm{~d}$ after application. Visual injury was based on combined visual score $(0=$ no visual crop injury and $100=$ complete plant death $)$ of leaf necrosis, 
chlorosis, and stunting. Plots were maintained weed-free using a combination of a preemergence application of chloroacetamide and atrazine herbicides, postemergence herbicides, and manual weed removal as needed.

\subsection{Statistical analysis}

Data were subjected to ANOVA using the general linear model procedure (PROC GLM) (SAS Institute, 2007). Percent data for weed control ratings were transformed to the arcsine prior to the analysis. Data were combined over years with low (2003 and 2005), medium (2007) and high (2004 and 2006) yields since no interactions within these environments were observed. Means were separated using Fisher's Protected LSD at $\mathrm{P}=0.05$. Linear regression analysis was performed using best-fit analysis determined with SigmaPlot (Vers. 8.02, SPSS Inc., Chicago, IL).

\section{Results and discussion}

\subsection{DDG rates}

This research was conducted on drought prone, claypan soils that are primarily a result of low precipitation during the summer months. Precipitation from 2003 to 2007 was presented in Figure 1. Years were grouped into high, medium, and low yield environments. Data were combined within these yield environments since no interactions existed. Initial soil test $\mathrm{P}$ was 92 to $149 \mathrm{~kg} \mathrm{ha}^{-1}$, and exchangeable $\mathrm{K}$ was 515 to $721 \mathrm{~kg} \mathrm{ha}^{-1}$, Ca was 4449 to $5994 \mathrm{~kg} \mathrm{ha}^{-1}$, and Mg was 527 to $610 \mathrm{~kg} \mathrm{ha}^{-1}$ from 2003 to 2007 (Table 2). All these soil test values were in the medium to very high range for Missouri soil test interpretations (Buchholz, 1992). Therefore, crop response from a balanced N-P-K source was not expected and not included in this experiment. Initial soil organic matter levels ranged from 29 to $32 \mathrm{~g} \mathrm{~kg}^{-1}$ and pH $(0.01$ $M \mathrm{CaCl}_{2}$ ) from 6.5 to 6.8 from 2003 to 2007 (Table 2). DDGs had an average $\mathrm{pH}$ of $4.15 \pm 0.15$ which may lower soil $\mathrm{pH}$ when applied at high rates (Table 1). No significant effect of DDGs on soil $\mathrm{pH}$ was observed in low, medium and high yielding years (Table 3). When combined over all five years, soil pH was lower when DDGs were applied at 3600 $\mathrm{kg} \mathrm{ha}^{-1}$ compared to the non-treated control $(\mathrm{P} \leq 0.08)$. The effect of manure and organic fertilizer sources on soil $\mathrm{pH}$ depended on the source (Curnoe et al., 2006). Long-term manure applications have increased pH (Eghball, 2002) in some instances and lowered soil pH (Meng, Ding, \& Cai, 2005) in others.

Soil tests after harvest also indicated no difference in soil organic matter, soil test $\mathrm{P}$, and exchangeable $\mathrm{K}, \mathrm{Ca}$, or $\mathrm{Mg}$ concentrations among DDG rates for low, medium, and high yield environments (Table 3). Beef cattle and swine manure applications to corn increased organic matter, P, and K concentration (Eghball, 2002; Singer et al., 2004) while dairy cattle manure had no effect on soil organic C, P, and K concentrations (Lithourgidis et al., 2007). Paper mill waste applications caused a temporary increase in soil organic matter (Curnoe et al. 2006). The N/P ratio for DDGs was 5.5 (Table 1) which is close to the N/P corn grain uptake ratio of 5.9 reported by Gilbertson et al. (1979); therefore, no change in soil $\mathrm{P}$ concentration should occur using DDGs as a fertilizer source.

The organic production system used for this experiment selected for large-seeded broadleaf weeds over time including common cocklebur $\left(40\right.$ plants $\left.\mathrm{m}^{-2}\right)$ and jimsonweed $\left(50\right.$ plants $\left.\mathrm{m}^{-2}\right)$. There was no effect of DDGs on either weed species during the five years of research (data not presented). Other research has indicated that corn gluten meal at 324 $\mathrm{g} \mathrm{m}^{-2}$ suppressed small-seeded broadleaf and grass weeds when applied preemergence or preplant incorporated, but little effect on large seeded broadleaf weed suppression such as velvetleaf (Abutilon theophrasti Medik.) was reported (Bingaman \& Christians, 1995; McDade \& Christians, 2000). For organic production, application of a fertilizer source such as DDGs that could supply nutrients, act as a soil conditioner, and suppress weed growth would be a valuable input. However, DDGs were not effective in weed suppression in this study.

There was no effect of DDG rate on harvested corn population (data not presented) which was similar to research evaluating low rates of incorporated corn gluten meal on sweet corn survival (McDade \& Christians, 2000). Grain oil concentration was reduced $2.5 \mathrm{~g} \mathrm{~kg}^{-1}$ with DDGs at $3600 \mathrm{~kg} \mathrm{ha}^{-1}$ in a low yield environment, but DDG rate did not affect oil concentration in medium and high yield environments (Table 3). Protein concentration increased 7.5 to $12.0 \mathrm{~g}$ $\mathrm{kg}^{-1}$ as DDG rate increased while starch decreased 6.7 and $11.2 \mathrm{~g} \mathrm{~kg}^{-1}$ in high and medium yield years, respectively. Extractable starch decreased 11.7 to $20.8 \mathrm{~g} \mathrm{~kg}^{-1}$ in low to high yield environments as the DDG rate increased from 0 to $3600 \mathrm{~kg} \mathrm{ha}^{-1}$. This was similar to site-specific evaluations of preplant and sidedress $\mathrm{N}$ rates on corn grain composition (Singh et al., 2005).

Since rainfall was limiting in 2003 and 2005 (Figure 1), no grain yield response to DDG rates was observed (Figure 2). Corn grain yield increased 2500 and $2300 \mathrm{~kg} \mathrm{ha}^{-1}$ with DDGs at $3600 \mathrm{~kg} \mathrm{ha}^{-1}$ in medium (2007) and high (2004 and 2006) yield environments, respectively (Figure 2). Grain yield increased 1.41 and $1.56 \mathrm{~kg} \mathrm{ha}^{-1}$ for every $\mathrm{kg} \mathrm{ha}^{-1}$ of DDGs applied in medium and high yield environments, respectively.

\subsection{DDGs and conventional $N$ sources}

Data were combined over low, medium, and high yield environments similar to the rate experiments since no interactions existed within these environmental classifications. DDGs caused no visual injury to corn plants up to $21 \mathrm{~d}$ after emergence, and no differences in harvested population were observed from 2004 to 2007 (data not presented). In 
2003 and 2005, rainfall was limited (Figure 1) and there was no significant yield response to the DDG treatment compared to the control (Table 4), which was similar to the rate experiment. However, corn grain yield increased 3080 and $3580 \mathrm{~kg} \mathrm{ha}^{-1}$ with $\mathrm{N}$ supplied by PCU and anhydrous ammonia treatments, respectively. DDGs increased grain yield over the non-treated control 2820 to $4390 \mathrm{~kg} \mathrm{ha}^{-1}$ in medium and high yield environments. The prediction equations from the rate experiment (Figure 2) indicated an expected yield of 7420 and $11340 \mathrm{~kg} \mathrm{ha}^{-1}$ which was similar to the observed 8600 and $11300 \mathrm{~kg} \mathrm{ha}^{-1}$ yields for medium and high yield environments, respectively, in this experiment. Grain yield with DDGs was similar to anhydrous ammonia in 2007. The use of DDGs as a fertilizer source for corn was more consistent in medium and high yield environments, but grain yields indicated that the availability of nutrients from DDGs was less than a slow-release PCU fertilizer source or anhydrous ammonia in a high yield environment. Grain oil was not affected by the N sources evaluated in this experiment (Table 4). Protein concentration was maximized as yield increased while starch and extractable starch concentrations decreased. Incorporation of DDGs with tillage or changes in DDG particle size (Rausch et al., 2005) may increase nutrient availability to the plant, but changes in management and application rate may also increase toxicity to corn (McDade \& Christians, 2000). Combining synthetic $\mathrm{N}$ fertilizer with soil organic amendments may improve crop response, especially with organic materials with high $\mathrm{C}: \mathrm{N}$ ratios, which may result in net $\mathrm{N}$ immobilization (Bellamy, Chong, \& Cline, 1995). Additional strategies to overcome potential $\mathrm{N}$ immobilization from high $\mathrm{C}: \mathrm{N}$ organic soil amendments include mixture with higher $\mathrm{N}$-containing organic materials (e.g. poultry litter), composting prior to application, and delaying planting after application of the organic soil amendment (Motavalli \& Diambra, 1997).

\section{Conclusions}

The results of these field studies indicate that DDGs may be utilized as a fertilizer source for corn production. However, agronomic performance was dependant on rainfall and growing conditions during the year. Grain yield increased 1.41 and $1.56 \mathrm{~kg} \mathrm{ha}^{-1}$ for every $\mathrm{kg} \mathrm{ha}^{-1}$ of DDGs that were applied in medium and high yield environments, respectively. Corn raised in low yield environments did not respond to increasing DDG rates while PCU or anhydrous ammonia increased grain yields in these environments when compared to DDGs. Application rates of DDGs may need to be higher to attain grain yields equivalent to other $\mathrm{N}$ sources when surface applied. In this research, DDGs did not affect large seeded broadleaf weed or corn development, SOM, P, K, Ca, or Mg concentration. There was a decrease in soil $\mathrm{pH}$ when DDGs were applied at $3600 \mathrm{~kg} \mathrm{ha}^{-1}$. Additional research is needed to identify consistent systems that provide responses to DDGs as a fertilizer source in low and medium yield environments if the cost of DDGs is low enough to be used as a fertilizer source for corn. This may require management changes, such as supplemental synthetic $\mathrm{N}$ fertilizer applications at reduced rates (N'Dayegamiye, 2006; Rashid \& Voroney, 2005;) or incorporation (McDade \& Christians, 2000) to achieve yields similar to conventional $\mathrm{N}$ fertilizer sources.

\section{References}

Aitken, M. N., Evans, B., \& Lewis, J. G. (1998). Effect of applying papermill sludge to arable land on soil fertility and crop yields. Soil Use and Management, 14, 215-222.

Bellamy, K. L., Chong, C., \& Cline, R. A. (1995). Paper sludge utilization in agriculture and container nursery culture. Journal of Environmental Quality, 24, 1074-1082.

Belyea, R. L., Rausch, R. D., \& Tumbleson, M .E. (2004). Composition of corn and distillers dry grains with solubles from dry grind ethanol processing. Bioresource Technology, 94, 293-298.

Bingaman, B. R., \& Christians, N. E. (1995). Greenhouse screening of corn gluten meal as a natural control product for broadleaf and grass weeds. HortScience, 30, 1256-1259.

Blanco-Canqui, H., Gantzer, C. J., Anderson, S. H., Alberts, E. E., \& Ghidey, F. (2002). Saturated hydraulic conductivity and its impact on simulated runoff for claypan soils. Soil Science Society of America Journal, 66, 1596-1602.

Buchholz, D. D. (1992). Soil test interpretations and recommendations handbook. Department of Agronomy, University of Missouri, Columbia.

Curnoe, W. E., Irving, D. C., Dow, C. B., Velema, G., \& Unc, A. (2006). Effect of spring application of a paper mill soil conditioner on corn yield. Agronomy Journal, 29, 423-429.

Edwards, J. H., Burt, E. C., Raper, R. L. \& Walker, R. H. (1995). Issues affecting application of noncomposted organic waste to agricultural land. In Karlen, D.L., R.J. Wright and W.O. Kemper (eds.) Agricultural utilization of urban and industrial by-products. (pp. 225-249). ASA Special Publication No. 58. American Society of Agronomy, Madison, WI.

Eghball, B. (2002). Soil properties as influenced by phosphorus- and nitrogen-based manure and composed applications. Agronomy Journal, 94, 128-135. 
Erickson, G. E., Klopfenstein, T. J., Adams, D. C., \& Rasby, R. J. (2005). General overview of feeding corn milling co-products to beef cattle. In Corn processing co-products manual. (pp. 3-12). Nebraska Corn Board and University of Nebraska-Lincoln. Association of American Feed Control Officials Official Publication. Oxford, IN.

Gale, E. S., Sullivan, D. M., Cogger, C. G., Bary, A. I., Hemphill, D. D., \& Myhre, E. A. (2006). Estimating plant-available nitrogen release from manures, composts, and specialty products. Journal of Environmental Quality, 35, 2321-2332.

Gilbertson, C. B., Norstadt, F. A., Mathers, A. C., Holt, R. F., Shuler, L. R., Barnett, A. P., McCalla, T. M., Onstad, C. A., Young, R. A., Christensen, L. A., \& Van Dyne, D. L. (1979). Animal waste utilization on cropland and pastureland: A manual for evaluating agronomic and environmental effects. USDA Utilization Research Report No. 6. U.S. Government Printing Office, Washington, D.C.

Harris, H. L., Cupp, A. S., Roberts, A. J., \& Funston, R. N. (2008). Utilization of soybeans or corn milling by-products in beef heifer development diets. Journal of Animal Science, 86, 476-482.

Jilani, G., Akram, A., Ali, R. M., Hafeez, F. Y., Shamsi, I. H., Chaudhry, A. N., \& Chaudhry, A. G. (2007). Enhancing crop growth, nutrients availability, economics and beneficial rhizosphere microflora through organic and biofertilizers. Annals of Microbiology, 57, 177-183.

Lithoourgidis, A. S., Matsi, T., Barbayiannis, N., \& Dordas, C. A. (2007). Effect of liquid cattle manure on corn yield, composition, and soil properties. Agronomy Journal, 99, 1041-1047.

Martin, J. L., Cupp, A. S., Rasby, R. J., Hall, Z. C., \& Funston, R. N. (2007). Utilization of dried distillers grains for developing beef heifers. Journal of Animal Science, 85, 2298-2303.

Martinez Amezcua, C., Parsons, C. M., \& Noll, S. L. (2004). Content and relative bioavailability of phosphorus in distillers dried grains with solubles in chicks. Poultry Science, 83, 971-976.

McDade, M. C., \& Christians, N. E. (2000). Corn gluten meal—a natural preemergence herbicide: effect on vegetable seedling survival and weed cover. American Journal of Alternative Agriculture, 15, 189-191.

Meng, L., Ding, W., \& Cai, Z. (2005). Long-term application of organic manure and nitrogen fertilizer on $\mathrm{N}_{2} \mathrm{O}$ emissions, soil quality, and crop production in a sandy loam soil. Soil Biology and Biochemistry, 37, 2037-2045.

Motavalli, P. P., \& Diambra, O. H. (1997). Management of nitrogen immobilization from waste office paper applications to tropical Pacific Island soils. Compost Science and Utilization, 5, 71-80.

N'Dayegamiye, A. (2006). Mixed paper mill sludge effects on corn yield, nitrogen efficiency, and soil properties. Agronomy Journal, 98, 1471-1478.

Parcell, J. L., \& Westhoff, P. (2006). Economic effects of biofuel production on states and rural communities. Journal of Agricultural and Applied Economics, 38, 377-387.

Paulsen, M. R., Pordesimo, L. O., Singh, M., Mbuvi S. W., \& Ye, B. (2003). Maize starch yield calibrations with near infrared reflectance. Biosystems Engineering, 85, 455-460.

Paulsen, M. R., \& Singh, M. (2004). Calibration of a near-infrared transmission grain analyzer for extractable starch in maize. Biosystems Engineering, 89, 79-83.

Peters, J., Combs, S. M., Hoskins, B., Jarman, J., Kovar, J. L., Watson, M. E., Wolf, A. M., \& Wolf, N. (2003). Recommended methods of manure analysis. (pp. 57). University of Wisconsin Extension.

Rashid, M. T., \& Voroney, R. P. (2004). Land application of oily food waste and corn production on amended soils. Agronomy Journal, 96, 997-1004.

Rashid, M. T., \& Voroney, R. P. (2005). Nitrogen fertilizer recommendations for corn grown on soils amended with oily food waste. Journal of Environmental Quality, 34, 2045-2051.

Rausch, K. D., \& Belyea, R. L. (2006). The future of coproducts from corn processing. Applied Biochemistry and Biotechnology, 128, 47-86.

Rausch, K. D., Belyea, R. L., Ellersieck, M. R., Singh, V., Johnston, D. B., \& Tumbleson, M. E. (2005). Particle size distributions of ground corn and DDGS from dry grind processing. Transactions of the ASAE, 48, 273-277.

SAS Institute. (2007). SAS Users' Guide, Version 9.1. SAS Institute, Cary, NC.

Singer, J. W., Kohler, K. A., Liebman, M., Richard, T. L. Cambardella, C. A., \& Buhler, D. D. (2004). Tillage and compost affect yield of corn, soybean, and wheat and soil fertility. Agronomy Journal, 96, 531-537.

Singh, M., Paulsen, M. R., Tian, L., \& Yao, H. (2005). Site-specific study of corn protein, oil, and extractable starch variability using NIT spectroscopy. Applied Engineering in Agriculture, 21, 329-251. 
Stevenson, F. J. (1985). Cycles of soil: Carbon, nitrogen, phosphorus, sulfur, micronutrients. (pp. 380) New York: John Wiley \& Sons.

Table 1. Average chemical and physical properties of dried distillers grains (DDGs) applied in the rate and $\mathrm{N}$ source experiments from 2003 to 2007.

\begin{tabular}{lc}
\hline Properties & $\begin{array}{c}\text { Total content mean } \\
\pm \text { standard deviation }\end{array}$ \\
& \\
\hline & \\
Moisture $\left(\mathrm{g} \mathrm{kg}^{-1}\right)$ & $102.0 \pm 1.4$ \\
Nitrogen $\left(\mathrm{g} \mathrm{kg}^{-1}\right)$ & $38.2 \pm 0.10$ \\
Phosphorus $\left(\mathrm{g} \mathrm{kg}^{-1}\right)$ & $6.9 \pm 0.02$ \\
Potassium $\left(\mathrm{g} \mathrm{kg}^{-1}\right)$ & $11.5 \pm 0.03$ \\
$\mathrm{Zn}\left(\mathrm{mg} \mathrm{kg}^{-1}\right)$ & $78.30 \pm 7.02$ \\
$\mathrm{Fe}\left(\mathrm{mg} \mathrm{kg}^{-1}\right)$ & $86.99 \pm 11.82$ \\
$\mathrm{Mn}\left(\mathrm{mg} \mathrm{kg}^{-1}\right)$ & $18.85 \pm 2.87$ \\
$\mathrm{Cu}\left(\mathrm{mg} \mathrm{kg}^{-1}\right)$ & $6.47 \pm 1.17$ \\
$\mathrm{NH}\left(\mathrm{mg} \mathrm{kg}^{-1}\right)$ & $334.12 \pm 60.89$ \\
$\mathrm{pH}$ & $4.15 \pm 0.15$ \\
$\mathrm{Electrical} \mathrm{conductivity}\left(\mathrm{S} \mathrm{m}^{-1}\right)$ & $0.66 \pm 0.38$ \\
\hline
\end{tabular}



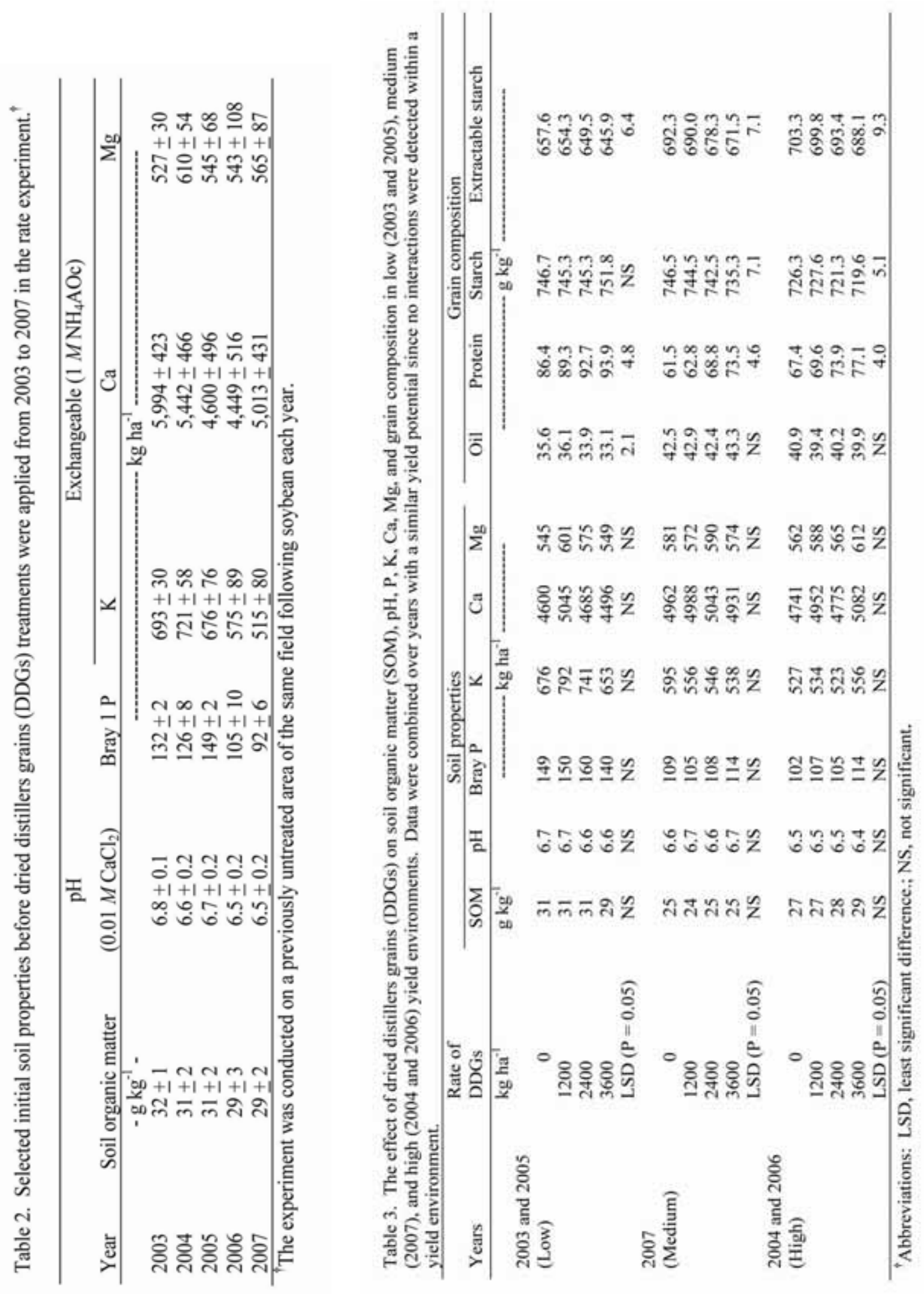


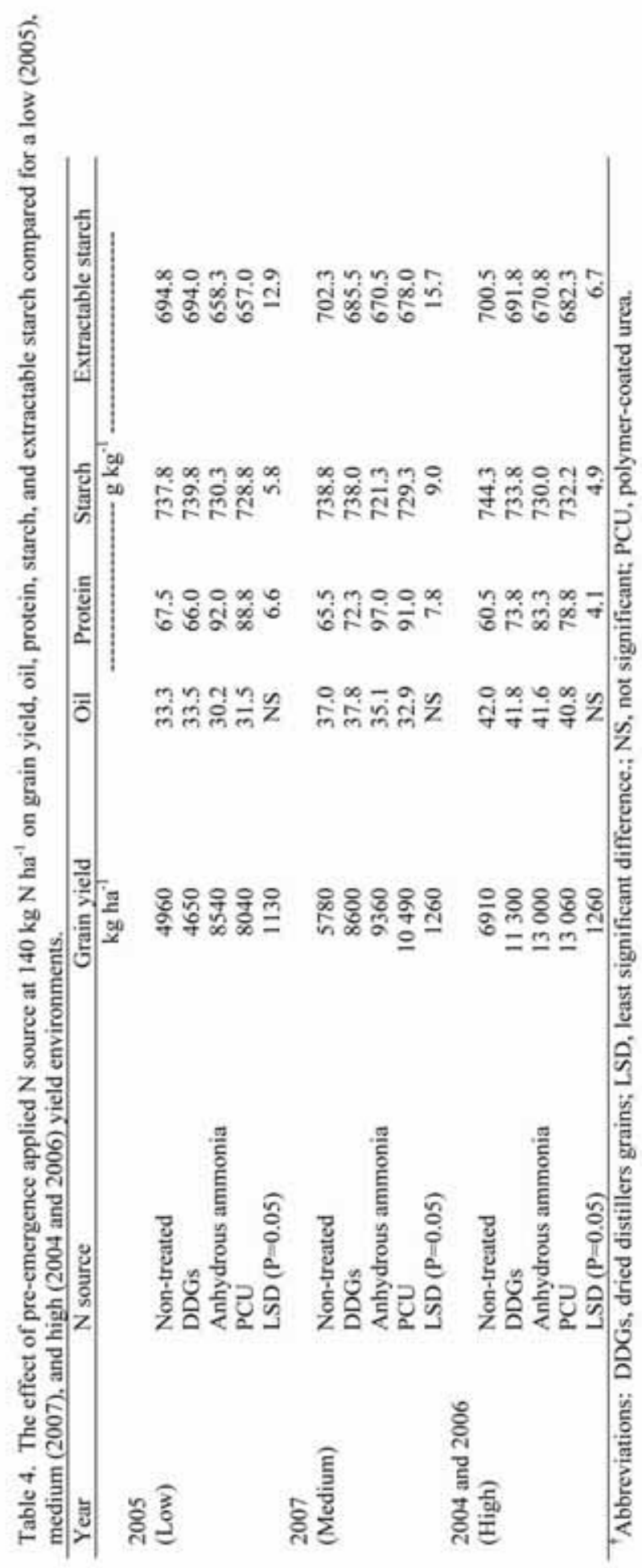



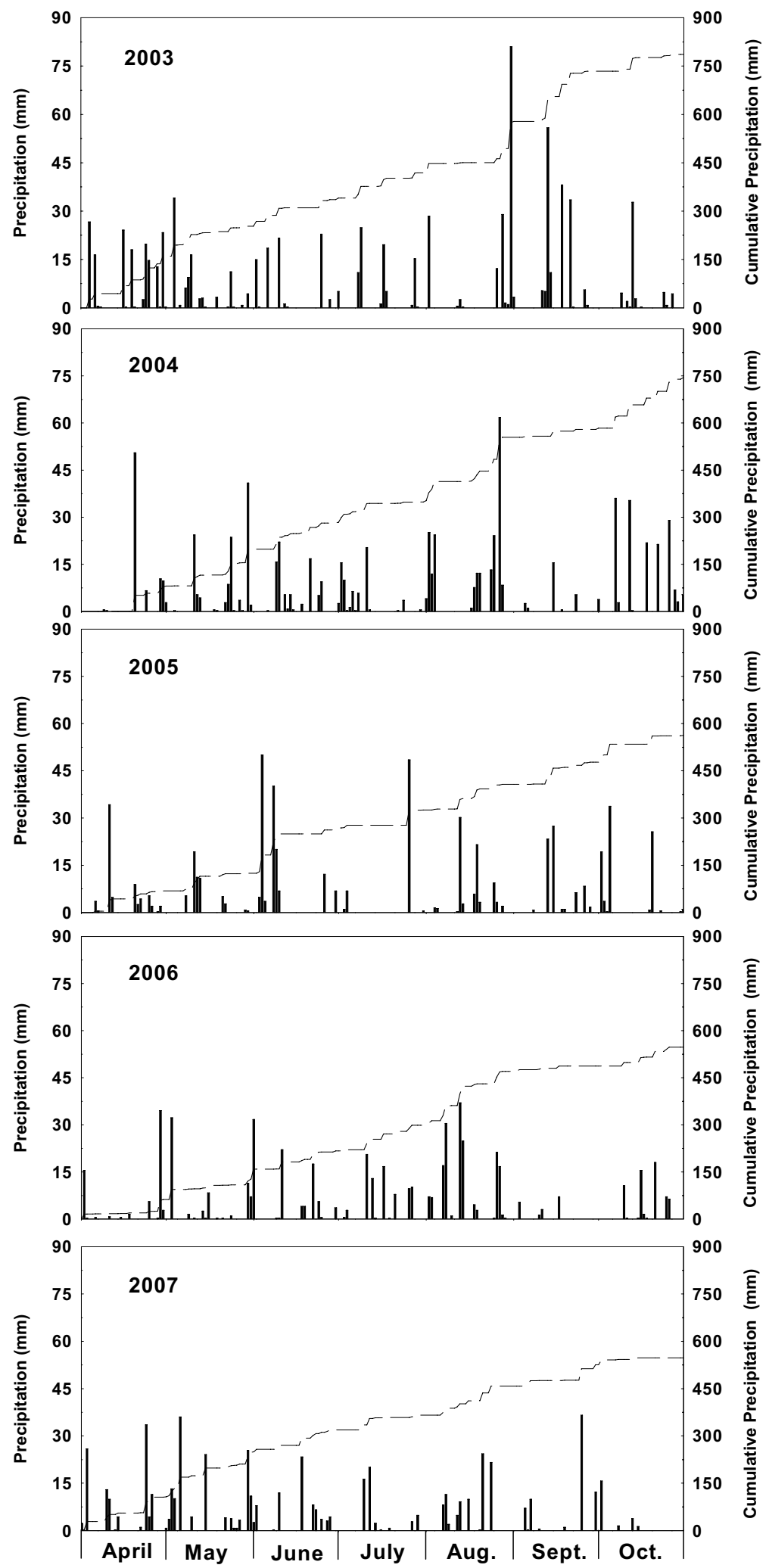

Figure 1. Daily (bars) and cumulative (line) precipitation during the growing season at the Greenley Research Center in Northeastern Missouri from 2003 to 2007 


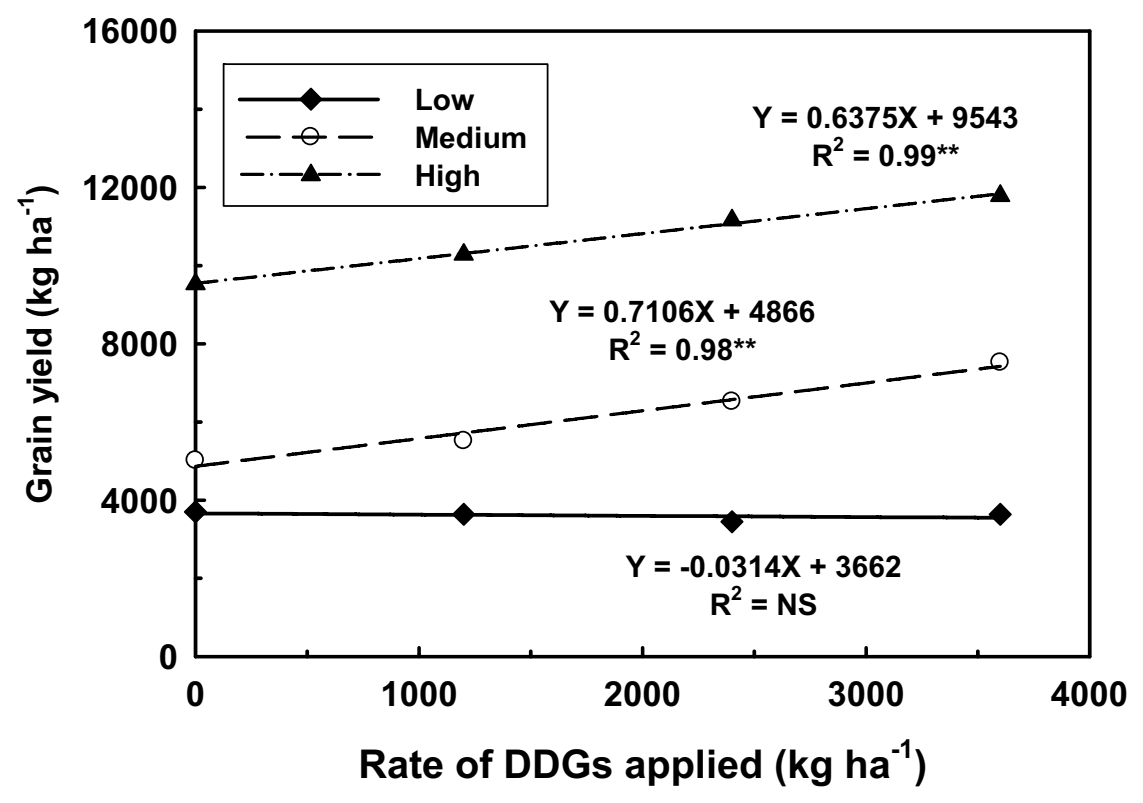

Figure 2. Grain yield response to an application of different rates of dried distiller grains (DDGs) in low (2003 and 2005), medium (2007) and high (2004 and 2006) yield environments. ** indicates statistical significance at $\mathrm{P}=0.01$ while NS $=$ no significant difference among DDG rates 